\title{
Pseudomonas cedrina subsp. fulgida subsp. nov., a fluorescent bacterium isolated from the phyllosphere of grasses; emended description of Pseudomonas cedrina and description of Pseudomonas cedrina subsp. cedrina subsp. nov.
}

\section{Correspondence Undine Behrendt ubehrendt@zalf.de}

\author{
Undine Behrendt, ${ }^{1}$ Peter Schumann, ${ }^{2}$ Jean-Marie Meyer ${ }^{3}$ \\ and Andreas Ulrich ${ }^{1}$
${ }^{1}$ Leibniz-Centre for Agricultural Landscape Research (ZALF), Institute of Landscape Matter Dynamics, Eberswalder Str. 84, D-15374 Müncheberg, Germany
${ }^{2}$ DSMZ-German Collection of Microorganisms and Cell Cultures, Inhoffenstraße 7B, D-38124 Braunschweig, Germany
${ }^{3}$ Département Microorganismes, Génomes, Environnement, Université Louis-Pasteur-CNRS, UMR 7156, F-67000 Strasbourg, France

\begin{abstract}
The taxonomic position of a group of four strains, isolated from the phyllosphere of grasses, within the species Pseudomonas cedrina was investigated. The isolates formed a separate cluster through ribotyping and MALDI-TOF MS, which could be clearly differentiated from the type strain of $P$. cedrina. The differences found between the patterns of the type strain of $P$. cedrina and the novel isolates were more distinct than those between the type strain and recognized species of the genus Pseudomonas, which were phylogenetically related by $16 \mathrm{~S}$ rRNA gene sequence analysis. Physiological characterization also revealed significant differences between the novel grass isolates and the type strain of $P$. cedrina. Siderotyping of the pyoverdines revealed identical pyoverdine-isoelectrofocusing patterns for the novel isolates and the type strain of $P$. cedrina. However, pyoverdine-mediated ${ }^{59}$ Fe cross uptake studies indicated differences in the siderotype. In contrast, phylogenetic analysis based on 16S rRNA gene sequence analysis and DNA-DNA hybridization studies (reassociation value $76.4 \%$ ) supported the affiliation of the novel isolates to the species $P$. cedrina. As a consequence of these observations, the splitting of the species $P$. cedrina into two novel subspecies Pseudomonas cedrina subsp. cedrina subsp. nov. (type strain CFML $96-198^{\top}=$ CIP $105541^{\top}=$ DSM $17516^{\top}$ ) and Pseudomonas cedrina subsp. fulgida subsp. nov. (type strain $P 515 / 12^{\top}=$ DSM $14938^{\top}=L M G 21467^{\top}$ ) is proposed.
\end{abstract}

The genus Pseudomonas is one of the genera harbouring the largest number of species and in which some taxonomic anomalies can be found. A multitude of genomovars and some species that should be considered synonymous have been described because the phenotypic characterizations did not reflect the results of the

\footnotetext{
Abbreviation: MALDI-TOF MS, matrix-assisted laser desorption ionization-time-of-flight mass spectrometry.

The GenBank/EMBL/DDBJ accession number for the 16S rRNA gene sequence of strain $P 515 / 12^{\top}$ is AJ492830.

A supplementary table detailing the differential physiological characteristics of $P$. cedrina subsp. cedrina subsp. nov., $P$. cedrina subsp. fulgida subsp. nov. and related species and a supplementary figure showing the Riboprint patterns of EcoRI-restricted DNA from the novel isolates and related strains are available with the online version of this paper.
}

phylogenetic analyses (Sutra et al., 1997; Gardan et al., 1999; Sikorski et al., 2005). On the other hand, strains or species that should be affiliated to recognized species on the basis of DNA-DNA relatedness values have been investigated, but differences in the phenotypic and molecular data have led to the description of novel subspecies (Peix et al., 2007) or, in some cases, have led to the proposal of separate species (Sikorski et al., 2001).

In the context of studying the diversity of fluorescent pseudomonads associated with the phyllosphere of grasses, several genotypes determined by ribotyping were characterized (Behrendt et al., 2003). One strain group, designated genotype E1 was found to be highly related to Pseudomonas cedrina on the basis of comparisons of the 16S rRNA gene sequence. DNA-DNA hybridization studies revealed a similarity value of $76.4 \%$ (replicate value $78.3 \%$ ) indicating 
a clear affiliation to the species $P$. cedrina according to taxonomic rules (Wayne et al., 1987). However, when compared to the strains of $P$. cedrina (originally published as Pseudomonas cedrella but corrected on validation) isolated from Lebanese spring water by Dabboussi et al. $(1998,1999)$, the isolates from grass showed differences in the phenotypic features that are normally used to distinguish species. For this reason, an extensive comparison of the novel grass isolates, strains P 515/12 ${ }^{\mathrm{T}}$, P 515/10, P 517/04 and P 530/23, with the type strain of $P$. cedrina was performed to clarify their taxonomic position.

Analysis of $16 \mathrm{~S}$ rRNA gene sequences of the novel grass isolate P $515 / 12^{\mathrm{T}}$ and P. cedrina CFML $96-198^{\mathrm{T}}$ revealed a close phylogenetic relationship with a sequence similarity value of $99.9 \%$ (Behrendt et al., 2003). Ribotyping was performed in order to investigate the strains using a method that has potential for higher taxonomic resolution. As demonstrated by several studies (Gardan et al., 1999; Sikorski et al., 2001; Behrendt et al., 2003; Clark et al., 2006; Behrendt et al., 2007), ribotyping is a highly discriminatory technique that is effective in differentiating strains inter- and intraspecifically within the genus Pseudomonas depending on the restriction enzymes used. The grass isolates and the type strains of related species that formed an internal cluster through the analysis of $16 \mathrm{~S}$ rRNA gene sequences (Behrendt et al., 2003) were studied by ribotyping with the restriction enzyme EcoRI. The analysis was performed with an automated RiboPrinter microbial characterization system (Qualicon Du Pont) as described by Behrendt et al. (2008). As already shown by Behrendt et al. (2003), the riboprint patterns of the novel grass isolates were highly similar to one another and formed a tight cluster (see Supplementary Fig. S1 in IJSEM online). They could be clearly differentiated from the pattern produced by the $P$. cedrina type strain, which was most similar to that of Pseudomonas jessenii DSM $17150^{\mathrm{T}}$. These clear differences obtained through the use of EcoRI, which is generally used to discriminate between Pseudomonas species, indicated that the grass isolates formed a separate group within the species $P$. cedrina.

Another powerful fingerprint technique that enables differentiation at the genus, species and sometimes, even strain level is matrix-assisted laser desorption ionization-time-offlight mass spectrometry (MALDI-TOF MS) (Conway et al., 2001; Fenselau \& Demirev, 2001; Stackebrandt et al., 2005; Valentine et al., 2005). MALDI-TOF MS analysis of the novel grass isolates and their close phylogenetic relatives as determined by $16 \mathrm{~S}$ rRNA gene sequence analysis (Behrendt et al., 2003) was performed according to the method of Tóth et al. (2008). As shown in Fig. 1, the grass isolates formed a cluster that was separated from the type strain of P. cedrina and related Pseudomonas species by clear differences in spectral patterns. Comparable to the ribotyping results, the spectra of the type strain of $P$. cedrina were closer to those of representative strains of other Pseudomonas species than to those of the group of novel grass isolates. These results supported the assumption that the novel strains formed a separate group within the species $P$. cedrina.
Characterization of pyoverdines by siderotyping has shown that these molecules are efficient taxonomical markers for the classification of fluorescent pseudomonads at the species level (Meyer et al., 2002, 2007; Meyer \& Geoffroy, 2004). The siderotypes of the grass isolates were compared with those of the P. cedrina type strain. Cultures for pyoverdine production and the electrophoretic characterization of the pyoverdine isoforms that accumulated in the growth media were performed according to Meyer et al. (1998), with the exception of the isoelectric $\mathrm{pH}(\mathrm{pI})$ values, which were determined using an internal standard made from a mixture of pyoverdines with defined $\mathrm{pI}$ values, as described by Fuchs et al. (2001). The purification of pyoverdines with the XAD chromatographic procedure and their use in pyoverdine-mediated ${ }^{59} \mathrm{Fe}$ uptake were performed as described previously (Meyer et al., 1998). The novel strains displayed identical pyoverdine-isoelectrofocusing patterns with one isoform band at pI 7.3. In contrast, studies of pyoverdine-mediated iron cross uptake revealed differences in the siderotype (data not shown). While the type strain of $P$. cedrina was able to use the pyoverdines of the novel grass isolates at a similar efficiency to its own pyoverdine, the grass isolates were unable to uptake the pyoverdine from the type strain. These results indicated that the type strain formed another siderovar with a different pyoverdine from the novel grass isolates, but had a supplementary pyoverdine-Fe receptor that recognized the pyoverdine of the grass isolates. Thus, the results of siderotyping confirmed the grass isolates separate group position in the species $P$. cedrina.

An extensive investigation of the physiological characteristics of the novel isolates and the type strain of $P$. cedrina was carried out using API 20NE test strips (bioMérieux) and Biolog GN MicroPlates (Biolog Inc.) according to the manufacturer's instructions. Additional physiological and morphological features were determined by methods described previously (Behrendt et al., 1999, 2008). Ice nucleation activity of the novel isolates was tested at -5 and $-10{ }^{\circ} \mathrm{C}$ according to the method of Hildebrand et al. (1994). As shown in Table 1, the novel isolates displayed high conformity with each other as regards phenotypic features. Using Biolog GN MicroPlates, differences in the intensity of oxidation were noted for only a few carbohydrates. The utilization of L-ornithine differed between the strains. Whilst strain P $515 / 12^{\mathrm{T}}$ did not use this substrate, the other novel isolates showed a weak reaction. In contrast, comparisons between the novel isolates and the type strain of $P$. cedrina revealed several differences in physiological characteristics (Table 1). Particularly, the different reaction for arginine dihydrolase was remarkable as this feature is generally species-specific and is an important component of the levan, oxidase, potato rot, arginine dihydrolase, tobacco hypersensitivity (LOPAT) test that is used for the primary differentiation of saprophytic and phytopathogenic species of fluorescent pseudomonads (Rudolph et al., 1990). Furthermore, the differences in substrate utilization found between $P$. 


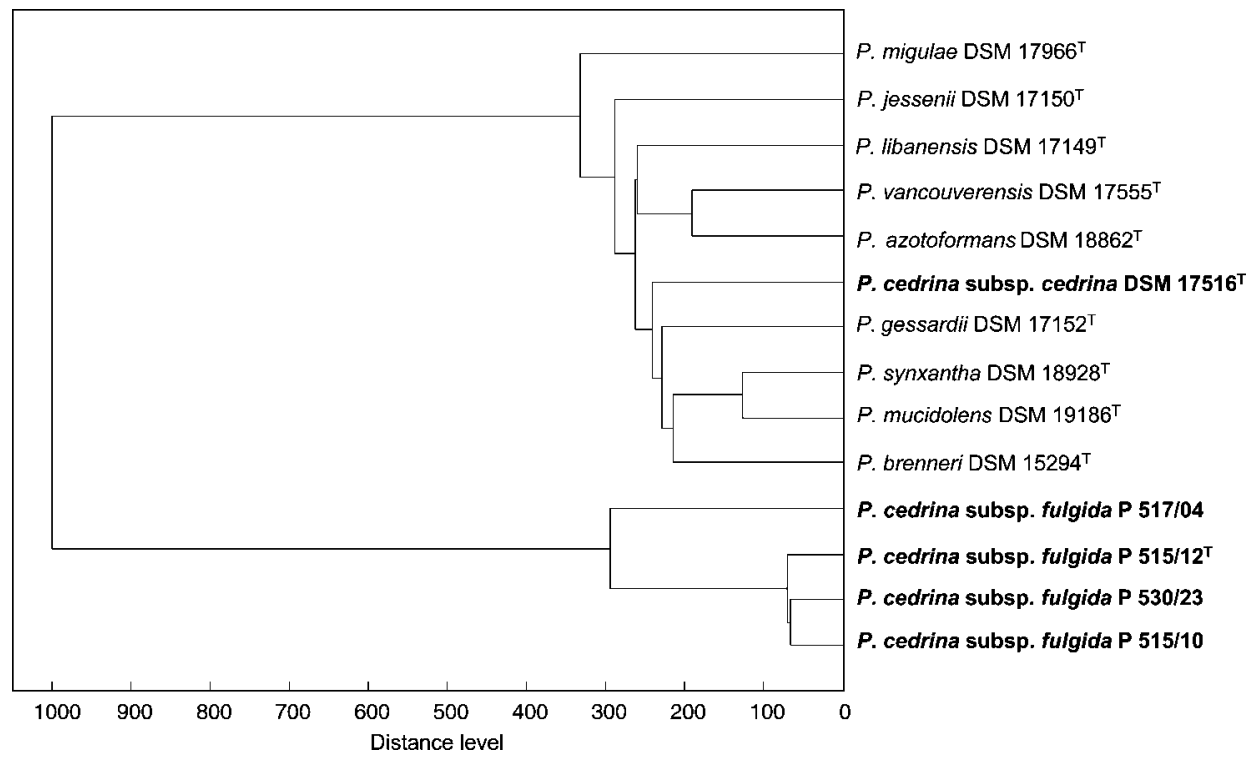

Fig. 1. Dendrogram generated by BioTyper software (version 1.1, Bruker Daltonics) showing the similarity of MALDI-TOF mass spectra of cell extracts of the novel grass isolates, the type strain of $P$. cedrina and highly related species of the genus Pseudomonas [as determined by 16S rRNA gene sequence analysis (Behrendt et al., 2003)].

Table 1. Physiological characteristics of $P$. cedrina CFML $96-198^{\top}$ and the four novel isolates from grass

Strains: 1, P. cedrina CFML 96-198 ${ }^{\mathrm{T}}$; 2, P 515/12 ${ }^{\mathrm{T}}$; 3, P 515/10; 4, P $517 / 04 ; 5$, P 530/23. Characteristics corresponding to all strains are given in the emended description of $P$. cedrina. + positive; - , negative; $\mathrm{w}$, weakly positive.

\begin{tabular}{|c|c|c|c|c|c|}
\hline Characteristic & 1 & 2 & 3 & 4 & 5 \\
\hline Arginine dihydrolase & + & - & - & - & - \\
\hline Formation of levan from sucrose & + & - & - & - & - \\
\hline Reduction of nitrates to nitrites & + & - & - & - & - \\
\hline Gelatin hydrolysis & + & - & - & - & - \\
\hline \multicolumn{6}{|c|}{ Utilization on Biolog GN microplates: } \\
\hline Adonitol & + & - & - & - & - \\
\hline Alaninamide & - & + & + & + & + \\
\hline i-Erythritol & + & - & - & - & - \\
\hline DL- $\alpha$-Glycerol phosphate & - & + & + & + & + \\
\hline Glycyl L-glutamic acid & + & + & $\mathrm{W}$ & $\mathrm{W}$ & $\mathrm{w}$ \\
\hline$p$-Hydroxyphenylacetic acid & + & - & - & - & - \\
\hline myo-Inositol & - & + & + & + & + \\
\hline$\alpha$-Ketovaleric acid & + & + & $\mathrm{W}$ & $\mathrm{W}$ & $\mathrm{w}$ \\
\hline L-Ornithine & - & - & $\mathrm{w}$ & $\mathrm{W}$ & $\mathrm{W}$ \\
\hline Psicose & - & $\mathrm{w}$ & $\mathrm{w}$ & $\mathrm{w}$ & + \\
\hline Putrescine & - & $\mathrm{w}$ & $\mathrm{w}$ & + & $\mathrm{W}$ \\
\hline Quinic acid & - & + & $\mathrm{W}$ & $\mathrm{w}$ & W \\
\hline L-Rhamnose & + & - & - & - & - \\
\hline D-Serine & - & $\mathrm{W}$ & $\mathrm{W}$ & $\mathrm{w}$ & w \\
\hline D-Sorbitol & + & - & - & - & - \\
\hline Sucrose & + & - & - & - & - \\
\hline D-Trehalose & + & - & - & - & - \\
\hline Uridine & + & $\mathrm{w}$ & $\mathrm{W}$ & $\mathrm{w}$ & W \\
\hline Xylitol & + & - & - & - & - \\
\hline
\end{tabular}

cedrina and the novel grass isolates with the Biolog GN MicroPlates were considerable and were more significant than the differences previously found between some recognized species of the genus (Behrendt et al., 2007). Thus, the results of the phenotypic characterization performed in this study substantiated the conclusion by Behrendt et al. (2003) that the novel isolates form a separate phenotypic group in the species $P$. cedrina.

In summary, the novel isolates from grass could be clearly discriminated from the type strain of $P$. cedrina by ribotyping, MALDI-TOF MS analysis, siderotyping and physiological characterization, although the phylogenetic analysis of Behrendt et al. (2003) demonstrated an affiliation to the species $P$. cedrina. On this basis, the novel isolates merit a separate taxonomic status at the subspecies level and thus the name Pseudomonas cedrina subsp. fulgida subsp. nov. is proposed. According to Rule $40 \mathrm{~b}$ of the Bacteriological Code (Lapage et al., 1992), the description of a novel subspecies necessitates the proposal of the subspecies Pseudomonas cedrina subsp. cedrina subsp. nov. The description of $P$. cedrina (Dabboussi et al., 1999) is therefore emended. As shown in Supplementary Table S1 (available in IJSEM online), both subspecies of $P$. cedrina can be differentiated from their phylogenetic neighbours by physiological characteristics despite the emendation of the species description.

\section{Emended description of Pseudomonas cedrina corrig. Dabboussi et al. 2002}

Possesses the following characteristics in addition to those described by Dabboussi et al. (1999). Cells are motile by 
means of one or two polar flagella. All strains are positive for the utilization of $\mathrm{N}$-acetyl-D-glucosamine, L-arabinose, Darabitol, caprate, citrate, D-fructose, D-galactose, $\alpha$-Dglucose, gluconate, D-mannitol, D-mannose, methyl pyruvate, monomethyl succinate, acetic acid, cis-aconitic acid, citric acid, formic acid, D-galactonic acid lactone, Dgalacturonic acid, D-gluconic acid, D-glucosaminic acid, Dglucuronic acid, $\alpha$-hydroxybutyric acid, $\beta$-hydroxybutyric acid, $\alpha$-ketobutyric acid, $\alpha$-ketoglutaric acid, DL-lactic acid, malate, malonic acid, propionic acid, D-saccharic acid, succinic acid, bromosuccinic acid, succinamic acid, glucuronamide, D-alanine, L-alanine, L-alanyl glycine, L-asparagine, L-aspartic acid, L-glutamic acid, L-histidine, hydroxy Lproline, L-leucine, L-proline, L-pyroglutamic acid, L-serine, L-threonine, $\gamma$-aminobutyric acid, urocanic acid, inosine, 2aminoethanol and glycerol. None of the strains uses adipate, $\alpha$-cyclodextrin, dextrin, glycogen, Tweens 40 or $80, N$-acetylD-galactosamine, cellobiose, L-fucose, gentiobiose, $\alpha$-lactose, $\alpha$-D-lactose, lactulose, maltose, D-melibiose, methyl $\beta$-Dglucoside, phenylacetate, D-raffinose, turanose, $\gamma$-hydroxybutyric acid, itaconic acid, sebacic acid, glycyl L-aspartic acid, L-phenylalanine, DL-carnitine, thymidine, phenylethylamine, 2,3-butanediol, glucose 1-phosphate or glucose 6phosphate. Oxidase and catalase reactions are positive whereas DNase, $\beta$-galactosidase and urease activities are negative. The strains do not produce indole from tryptophan. Hydrolysis of aesculin and tyrosine is negative. All strains are able to grow on cetrimide agar. $\beta$-Haemolysis of sheep blood does not occur.

\section{Description of Pseudomonas cedrina subsp. fulgida subsp. nov.}

Pseudomonas cedrina subsp. fulgida (ful'gi.da. L. fem. adj. fulgida flashing, glittering, shining, pertaining to the bright fluorescence).

Cells are Gram-negative, non-spore-forming rods of about $0.8 \mu \mathrm{m}$ in diameter and $2.5-4.2 \mu \mathrm{m}$ in length that occur singly. They are motile by one or two polar flagella. The white-yellowish colonies on King B medium are smooth with regular margins and they produce a pigment that gives off a light yellow-green fluorescence when irradiated with UV-light. Metabolism is aerobic. Does not hydrolyse starch or casein. Ice nucleation activity and formation of $\mathrm{H}_{2} \mathrm{~S}$ from sodium thiosulphate are negative. Optimal growth temperature is $21{ }^{\circ} \mathrm{C}$. Growth can be observed at $4{ }^{\circ} \mathrm{C}$, but none of the isolates are able to grow at $41{ }^{\circ} \mathrm{C}$. Further physiological features are presented in Table 1.

The type strain, P $515 / 12^{\mathrm{T}}\left(=\mathrm{DSM} 14938^{\mathrm{T}}=\mathrm{LMG} 21467^{\mathrm{T}}\right)$, was isolated from the phyllosphere of grasses in Paulinenaue (Germany).

\section{Description of Pseudomonas cedrina subsp. cedrina subsp. nov.}

Pseudomonas cedrina subsp. cedrina (ce'dri.na. L. fem. adj. cedrina of a cedar tree, the characteristic tree of Lebanon, the country from which isolates were taken).
The description is essentially as given by Dabboussi et al. (1999). Additional physiological features determined for the type strain are shown in Table 1.

The type strain, CFML $96-198^{\mathrm{T}}\left(=\mathrm{CIP} 105541^{\mathrm{T}}=\mathrm{DSM}\right.$ $17516^{\mathrm{T}}$ ), was isolated from Lebanese spring waters.

\section{Acknowledgements}

We wish to thank Mrs B. Selch and Mrs S. Weinert (ZALFMüncheberg), Mrs A. Wasner (DSMZ-Braunschweig) and Mrs C. Gruffaz (Université Louis-Pasteur-CNRS) for their excellent technical assistance. Furthermore, we would like to acknowledge Dr H. G. Trüper (Rheinische Friedrich-Wilhelm-Universität, Bonn) for his help with the Latin construction of the species name.

\section{References}

Behrendt, U., Ulrich, A., Schumann, P., Erler, W., Burghardt, J. \& Seyfarth, W. (1999). A taxonomic study of bacteria isolated from grasses: a proposed new species Pseudomonas graminis sp. nov. Int $J$ Syst Bacteriol 49, 297-308.

Behrendt, U., Ulrich, A. \& Schumann, P. (2003). Fluorescent pseudomonads associated with the phyllosphere of grasses; Pseudomonas trivialis sp. nov., Pseudomonas poae sp. nov. and Pseudomonas congelans sp. nov. Int J Syst Evol Microbiol 53, 14611469.

Behrendt, U., Ulrich, A., Schumann, P., Meyer, J.-M. \& Spröer, C. (2007). Pseudomonas lurida sp. nov., a fluorescent species associated with the phyllosphere of grasses. Int J Syst Evol Microbiol 57, 979-985.

Behrendt, U., Ulrich, A. \& Schumann, P. (2008). Chryseobacterium gregarium sp. nov., isolated from decaying plant material. Int J Syst Evol Microbiol 58, 1069-1074.

Clark, L. L., Dajcs, J. J., McLean, C. H., Bartell, J. G. \& Stroman, D. W. (2006). Pseudomonas otitidis sp. nov., isolated from patients with otic infections. Int J Syst Evol Microbiol 56, 709-714.

Conway, G. C., Smole, S. C., Sarracino, D. A., Arbeit, R. D. \& Leopold, P. E. (2001). Phyloproteomics: species identification of Enterobacteriaceae using matrix-assisted laser desorption/ionization time-of-flight mass spectrometry. J Mol Microbiol Biotechnol 3, 103-112.

Dabboussi, F., Hamze, M., Elomari, M., Verhille, S., Baida, N., Izard, D. \& Leclerc, H. (1998). A numerical study of fluorescent Pseudomonas strains isolated from three Lebanese spring waters. J Eur Hydrol 28, 325-338.

Dabboussi, F., Hamze, M., Elomari, M., Verhille, S., Baida, N., Izard, D. \& Leclerc, H. (1999). Taxonomic study of bacteria isolated from Lebanese spring waters: proposal for Pseudomonas cedrella sp. nov. and P. orientalis sp. nov. Res Microbiol 150, 303-316.

Fenselau, C. \& Demirev, P. A. (2001). Characterization of intact microorganisms by MALDI mass spectrometry. Mass Spectrom Rev 20, 157-171.

Fuchs, R., Schäfer, M., Geoffroy, V. \& Meyer, J.-M. (2001). Siderotyping - a powerful tool for the characterization of pyoverdines. Curr Top Med Chem 1, 31-57.

Gardan, L., Shafik, H., Belouin, S., Broch, R., Grimont, F. \& Grimont, P. A. D. (1999). DNA relatedness among the pathovars of Pseudomonas syringae and description of Pseudomonas tremae sp. nov. and Pseudomonas cannabina sp. nov. (ex Sutic and Dowson 1959). Int J Syst Bacteriol 49, 469-478.

Hildebrand, D. C., Schroth, M. N. \& Sands, D. C. (1994). Pseudomonas. In Laboratory Guide for Identification of Plant 
Pathogenic Bacteria, pp. 60-80. Edited by N. W. Schaad. St Paul, MN: American Phytopathological Society.

Lapage, S. P., Sneath, P. H. A., Lessel, E. F., Skerman, V. B. D., Seeliger, H. P. R. \& Clark, W. A. (editors) (1992). International Code of Nomenclature of Bacteria (1990 Revision). Bacteriological Code. Washington, DC: American Society for Microbiology.

Meyer, J.-M. \& Geoffroy, V. (2004). Environmental fluorescent Pseudomonas and pyoverdine diversity: how siderophores could help microbiologists in bacterial identification and taxonomy. In Iron Transport in Bacteria, pp. 451-468. Edited by J. H. Crosa, A. R. Mey \& S. M. Payne. Washington, DC: American Society for Microbiology.

Meyer, J.-M., Stintzi, A., Coulanges, V., Shivaji, S., Voss, J. A., Taraz, K. \& Budzikiewicz, H. (1998). Siderotyping of fluorescent pseudomonads: characterization of pyoverdines of Pseudomonas fluorescens and Pseudomonas putida strains from Antarctica. Microbiology 144, 3119-3126.

Meyer, J.-M., Geoffroy, V. A., Baida, N., Gardan, L., Izard, D., Lemanceau, P., Achouak, W. \& Palleroni, N. J. (2002). Siderophore typing, a powerful tool for the identification of fluorescent and nonfluorescent pseudomonads. Appl Environ Microbiol 68, 27452753.

Meyer, J.-M., Gruffaz, C., Tulkki, T. \& Izard, D. (2007). Taxonomic heterogeneity, as shown by siderotyping, of strains primarily identified as Pseudomonas putida. Int J Syst Evol Microbiol 57, 2543-2556.

Peix, A., Valverde, A., Rivas, R., Igual, J. M., Ramírez-Bahena, M. H., Mateos, P. F., Santa-Regina, I., Rodríguez-Barrueco, C., MartínezMolina, E. \& Velázquez, E. (2007). Reclassification of Pseudomonas aurantiaca as a synonym of Pseudomonas chlororaphis and proposal of three subspecies, P. chlororaphis subsp. chlororaphis subsp. nov., $P$. chlororaphis subsp. aureofaciens subsp. nov., comb. nov. and P. chlororaphis subsp. aurantiaca subsp. nov., comb. nov. Int J Syst Evol Microbiol 57, 1286-1290.
Rudolph, K., Roy, M. A., Sasser, M., Stead, D. E., Davis, D. E., Swings, M. \& Gosselé, F. (1990). Isolation of bacteria. In Methods in Phytobacteriology, pp. 43-86. Edited by Z. Klement, K. Rudolph \& D. C. Sands. Budapest: Akademiai Kiado.

Sikorski, J., Stackebrandt, E. \& Wackernagel, W. (2001). Pseudomonas kilonensis sp. nov., a bacterium isolated from agricultural soil. Int J Syst Evol Microbiol 51, 1549-1555.

Sikorski, J., Lalucat, J. \& Wackernagel, W. (2005). Genomovars 11 to 18 of Pseudomonas stutzeri, identified among isolates from soil and marine sediment. Int J Syst Evol Microbiol 55, 1767-1770.

Stackebrandt, E., Päuker, O. \& Erhard, M. (2005). Grouping myxococci (Corallococcus) strains by matrix-assisted laser desorption ionization time-of-flight (MALDI TOF) mass spectrometry: comparison with gene sequence phylogenies. Curr Microbiol 50, 71-77.

Sutra, L., Siverio, F., Lopez, M. M., Hunault, G., Bollet, C. \& Gardan, L. (1997). Taxonomy of Pseudomonas strains isolated from tomato pith necrosis: emended description of Pseudomonas corrugata and proposal of three unnamed fluorescent Pseudomonas genomospecies. Int J Syst Bacteriol 47, 1020-1033.

Tóth, E. M., Schumann, P., Borsodi, A. K., Kéki, Z., Kovács, A. L. \& Márialigeti, K. (2008). Wohlfahrtiimonas chitiniclastica gen. nov., sp. nov., a new gammaproteobacterium isolated from Wohlfahrtia magnifica (Diptera: Sarcophagidae). Int J Syst Evol Microbiol 58, 976-981.

Valentine, N., Wunschel, S., Wunschel, D., Petersen, C. \& Wahl, K. (2005). Effect of culture conditions on microorganism identification by matrix-assisted laser desorption ionization mass spectrometry. Appl Environ Microbiol 71, 58-64.

Wayne, L. G., Brenner, D. J., Colwell, R. R., Grimont, P. A. D., Kandler, O., Krichevsky, M. I., Moore, L. H., Moore, W. E. C., Murray, R. G. E. \& other authors (1987). International Committee on Systematic Bacteriology. Report of the ad hoc committee on reconciliation of approaches to bacterial systematics. Int J Syst Bacteriol 37, 463-464. 